\title{
Advances in understanding the molecular basis of skin
}

\section{fragility [version 1; peer review: 2 approved]}

\author{
Cristina Has (iD
}

Department of Dermatology and Venerology, Medical Center - University of Freiburg, Faculty of Medicine, University of Freiburg, Hauptstrasse 7, DE-79104, Freiburg, Germany

V1 First published: 06 Mar 2018, 7(F1000 Faculty Rev):279

https://doi.org/10.12688/f1000research.12658.1

Latest published: 06 Mar 2018, 7(F1000 Faculty Rev):279

https://doi.org/10.12688/f1000research.12658.1

\section{Abstract}

Skin fragility refers to a large group of conditions in which the ability of the skin to provide protection against trivial mechanical trauma is diminished, resulting in the formation of blisters, erosions, wounds, or scars. Acquired and physiological skin fragility is common; genetic disorders are rare but give insight into the molecular mechanisms ensuring skin stability. The paradigm is represented by inherited epidermolysis bullosa. This review is focused on recent advances in understanding the molecular basis of genetic skin fragility, including emerging concepts, controversies, unanswered questions, and opinions of the author. In spite of the advanced knowledge on the genetic causes of skin fragility, the molecular pathology is still expanding. Open questions in understanding the molecular basis of genetic skin fragility are the following: what are the causes of phenotypes which remain genetically unsolved, and what are the molecular modifiers which might explain phenotypic differences among individuals with similar mutations? New mutational mechanisms and new genes have recently been discovered and are briefly described here. Comprehensive next-generation sequencingbased genetic testing improved mutation detection and facilitated the identification of the genetic basis of unclear and new phenotypes. Characterization of the biochemical and cell biological consequences of the genetic variants is challenging and laborious but may represent the basis for personalized therapeutic approaches. Molecular modifiers of skin fragility have been uncovered in particular animal and genetic models but not in larger cohorts of patients. This scientific progress is the basis for revisions of the epidermolysis bullosa classification and for innovative therapeutic approaches designed for this intractable condition.

\section{Keywords}

Skin fragility, epidermolysis bullosa, genetic causes

\section{Open Peer Review}

Approval Status

1 2

version 1

06 Mar 2018

Faculty Reviews are review articles written by the prestigious Members of Faculty Opinions. The articles are commissioned and peer reviewed before publication to ensure that the final, published version is comprehensive and accessible. The reviewers who approved the final version are listed with their names and affiliations.

1. Gerhard Wiche, Perutz Laboratories,

University of Vienna, Vienna, Austria

2. Jakub Tolar, University of Minnesota,

Minneapolis, USA

Any comments on the article can be found at the end of the article. 
Corresponding author: Cristina Has (cristina.has@uniklinik-freiburg.de)

Author roles: Has C: Conceptualization, Data Curation, Formal Analysis, Funding Acquisition, Writing - Original Draft Preparation, Writing - Review \& Editing

Competing interests: No competing interests were disclosed.

Grant information: Debra International, CRC (SFB) 1140, and the Fritz Thyssen Foundation are acknowledged for funding. The funders had no role in study design, data collection and analysis, decision to publish, or preparation of the manuscript.

Copyright: $\odot 2018$ Has C. This is an open access article distributed under the terms of the Creative Commons Attribution License, which permits unrestricted use, distribution, and reproduction in any medium, provided the original work is properly cited.

How to cite this article: Has C. Advances in understanding the molecular basis of skin fragility [version 1; peer review: 2 approved] F1000Research 2018, 7(F1000 Faculty Rev):279 https://doi.org/10.12688/f1000research.12658.1

First published: 06 Mar 2018, 7(F1000 Faculty Rev):279 https://doi.org/10.12688/f1000research.12658.1 


\section{Molecular basis of skin fragility}

Skin fragility refers to a broad range of conditions in which the ability of the skin to provide protection against trivial mechanical stressors is not fully ensured, resulting in the formation of blisters, erosions, wounds, and ultimately scars. It is essentially due to the weakening (for example, decreased amount or functionality) of the structures which ensure cutaneous stability. The mechanical resilience of the cutaneous organ relies mainly on multimolecular suprastructures, which provide stable attachment of epidermal keratinocytes to each other (that is, desmosomes and tight junctions) and to the underlying connective tissue (that is, hemidesmosomes, focal adhesions, basement membrane, and anchoring fibrils) and regulate tissue homeostasis in critical cell processes that include tissue barrier function, cell proliferation, and migration. Furthermore, the keratin cytoskeleton confers structural support and deformability on keratinocytes, while the extracellular matrix and the collagen and elastic fibers are suited to cushion mechanical forces.

The relevance of the topic is high, since skin fragility is common and occurs in physiological, pathological, or iatrogenic situations. For example, neonatal and senescent skin is physiologically fragile because of functional immaturity or decline, respectively ${ }^{1,2}$. Acquired fragility of the skin is frequent in the clinical practice being associated with high morbidity and costs. It can be induced by photo damage, corticosteroids, diabetes, peripheral vascular disorders, autoimmune processes, and so on. Genetic disorders provide excellent models to understand the pathogenic mechanisms underlying skin fragility ${ }^{3}$. The prototype of genetic skin fragility disorders is represented by inherited epidermolysis bullosa (EB), which is the focus of this review. Other groups of disorders, such as peeling skin disorders, keratinopathic ichthyoses, pachyonychia congenita, and Ehlers-Danlos syndromes, also display features of skin fragility but will not be discussed here ${ }^{3}$. Mutations of the genes encoding the most prominent proteins with structural and scaffolding functions in the skin-such as keratins 5 and 14, plectin, bullous pemphigoid antigen 1e (BPAG1e), collagen XVII, integrin $\alpha 6 \beta 4$, laminin 332, or collagen VII-account for most cases of inherited EB. Based on the advances in understanding the molecular basis of skin fragility, the revised recommendations for EB classification extended the EB spectrum beyond the classic types to comprise disorders such as the Kindler syndrome, the acral peeling skin syndrome, the acantholytic EB, and desmosomal skin fragility diseases ${ }^{4,5}$.

Open questions in understanding the molecular basis of genetic skin fragility are (a) what are the causes of about $15 \%$ of the phenotypes which remain genetically unsolved by Sanger sequencing of candidate genes ${ }^{6}$ and (b) what are the molecular modifiers which might explain phenotypic differences among individuals with similar mutations? The results of comprehensive next-generation sequencing (NGS)-based genetic testing for EB published in the last four years shed some light on these questions.

\section{Old and new players in the mechanical stability of the skin}

Most studies using NGS-based genetic testing in EB cases in which clinical assessment, skin biopsy analysis, and/or Sanger sequencing of candidate genes had failed subclassification or identification of pathogenic mutations nevertheless revealed mutations in genes known to be associated with $\mathrm{EB}^{6-10}$. This finding is not unexpected and points to the fact that the clinical and molecular pathology of skin fragility is multifaceted and highly complex. Classic genotype-phenotype correlations in which lack of gene products, such as collagen VII or laminin 332 , lead to clear-cut clinical presentations of severe generalized dystrophic or junctional EB are just the "tip of the iceberg". At the "bottom of the iceberg", the spectrum of genetic skin fragility extends to mild phenotypes, which may remain underdiagnosed. These are characterized by one or more of the following features: occurrence of erosions, wounding, or scarring after minimal scratches but no blister formation, localized/acral blistering, onset of clinical manifestations in childhood or adult age, or improvement of the clinical manifestations with age. Such phenotypes result from mutations which induce moderate alterations in the abundance (that is, expression, stability, and size) or functionality (that is, processing, interactions, and dimerization/trimerization) of the respective proteins (examples reported in 11,12). On the other hand, comprehensive genetic analyses identified variants of uncertain/unknown significance (VUSs) ${ }^{13}$, which were predicted to affect gene transcription or splicing. Exhaustive workup, including RNA sequencing and protein biochemistry, is required to prove the pathogenicity of such VUSs and explain genotype-phenotype correlations (examples reported in 14-18).

Besides these general remarks, some genes/proteins and phenotypes are particularly interesting.

One example is plectin, a huge, $500 \mathrm{kD}$ plakin protein of the inner plaque of the hemidesmosomes. Its complexity is due to the existence of multiple isoforms with tissue-specific expression, a multitude of interaction partners within the intermediate filament, and actin adhesion complexes (reviewed in 19-23). Mutations in the gene encoding plectin, PLEC, result in "plectinopathies", including cutaneous or extracutaneous features: EB simplex with muscular dystrophy (MIM 226670), EB simplex with pyloric atresia (MIM 612138), EB simplex Ogna (MIM 131950), and muscular dystrophy, limb-girdle, type 2Q (MIM 613723). EB simplex Ogna is the only autosomal dominant condition associated with PLEC mutations. It was first recognized as a distinct disorder and later genetically solved by the late Tobias Gedde-Dahl and colleagues ${ }^{24,25}$. Clinically, it resembles localized or generalized intermediate EB simplex and lacks muscular dystrophy. It is caused by a specific amino acid substitution, exchanging an arginine residue with a tryptophan at position 2000, p.Arg2000Trp in the rod domain of plectin ${ }^{26,27}$. The molecular pathology was elucidated in detail in the mouse model $^{28}$. The mutation p.Arg2000Trp renders the coiled-coil 
rod domain of plectin more vulnerable to cleavage by calpains and other proteases activated in the epidermis but not in skeletal muscle. This results in insufficient protein levels of the hemidesmosome-associated plectin isoform $1 \mathrm{a}$, which is required for efficient hemidesmosome formation ${ }^{28}$.

In 2015, a mutation in exon 1a of PLEC (c.46C $>\mathrm{T}$, p.Arg16Ter), leading to the disruption of plectin isoform 1a, the dominant isoform in the epidermal basal cell layer, was shown to cause a new phenotype: autosomal-recessive skin-only EB simplex (designated as EB simplex with nail dystrophy, MIM 616487) ${ }^{29}$. Skin disease started with foot blisters at walking age and became generalized at puberty while sparing mucous membranes ${ }^{29}$. This phenotype was associated with hypoplastic hemidesmosomes, but screening for cardiomyopathy and muscle dystrophy showed no abnormalities ${ }^{29}$.

A similar example is the BPAG1, encoded by the dystonin gene $(D S T)$. The complexity also resides in the existence of different isoforms (epithelial, neuronal, and muscular) and molecular interactions (reviewed in 30). In humans, DST mutations, affecting distinct BPAG1 isoforms, lead to two autosomalrecessive disorders: (a) neuropathy, hereditary sensory and autonomic, type VI (MIM 614653) and (b) EB simplex, autosomal recessive 2 (MIM 615425). The epithelial isoform BPAG1e was considered a major scaffolding molecule in hemidesmosomes. However, mutations leading to premature termination codons in the coiled-coil domain led to a rather mild EB simplex, manifesting with lifelong trauma-induced blisters and erosions particularly affecting the extremities ${ }^{31-33}$, while distal truncation of BPAG1e was associated with EB simplex generalized intermediate with prurigo papules ${ }^{34}$. Recently, the first case with a mutation affecting an exon expressed in both the neuronal and the epithelial isoforms and a complex phenotype was reported ${ }^{35}$. Whole exome sequencing revealed compound heterozygous $D S T$ variants-c.3886A >G, p.Arg1296Ter in exon 29 (expressed in both epithelial and neuronal isoforms) and c.806C $>\mathrm{T}$, p.His269Arg in exon 7 (included in the neuronal isoform)-in a 17 -year-old female presenting with a complex phenotype consisting of both skin and neuronal involvement as well as iris heterochromia, cataract, hearing impairment, syringomyelia, behavioral and gastrointestinal issues, osteoporosis, and growth hormone deficiency ${ }^{35}$.

Besides, the kelch-like protein 24 (KLHL24) emerged as a new contributor to the stability of the $\operatorname{skin}^{36,37}$. Although an explanation for the genetically unsolved EB simplex cases was sought for many years, identification of KLHL24 mutations was unexpected and very little was known about this gene/protein ${ }^{38}$. The kelch-like family (KLHL proteins) comprises 42 proteins which contain a BTB domain which binds to cullin 3, a scaffold protein required for ubiquitination and proteasomal degradation of substrate proteins ${ }^{39,40}$. KLHL24 is expressed in the main skin cell types-keratinocytes, fibroblasts, and melanocytes-and in other tissues such as brain, liver, heart, skeletal muscle, kidney, pancreas, placenta, lung, and peripheral blood ${ }^{36,37}$. In neurons, KLHL24 binds to the C-terminal domain of the kaianate receptor GluR6 and regulates its function by interacting with
PICK1 (protein interacting with protein kinase C, alpha) ${ }^{41}$. All 26 EB simplex patients reported so far harbored monoallelic mutations in the translation initiation codon of KLHL24, c.1A>G, c. $1 \mathrm{~A}>\mathrm{T}, \quad$ c. $2 \mathrm{~T}>\mathrm{C}, \quad$ c. $3 \mathrm{G}>\mathrm{T}, \quad$ c. $3 \mathrm{G}>\mathrm{A}^{36,37,42}$. The consequence is the usage of a transcription initiation site located 29 codons downstream, resulting in an $\mathrm{N}$-terminal truncation. Based on experiments in recombinant expression systems, KLHL24 was proposed to function as a cullin 3-Rbx1 ubiquitin ligase substrate receptor for keratin 14. N-terminal truncated KLHL24 was more stable than its wild-type counterpart because of abolished autoubiquitination. This gain-of-function led to loss of keratin 14 in the skin of one patient and in a mouse model ${ }^{36}$. Although this straightforward hypothesis is very attractive, neither keratin 14 nor keratin 5 was significantly reduced in the skin or keratinocytes of the patients reported by other groups ${ }^{37,42}$. New reports are expected to clarify this controversy.

\section{Molecular modifiers of skin fragility}

Two exciting articles identifying modifiers in EB were published in 2014. Sproule et al. used a mouse model with a hypomorphic laminin $\gamma 2$ (Lamc2) allele that recapitulates generalized junctional EB to demonstrate the potent impact of genetic modifiers on the strength of dermal-epidermal adhesion and on the clinical severity of junctional $\mathrm{EB}^{43}$. Through an unbiased genetic approach involving a combination of quantitative trait locus (QTL) mapping and positional cloning, the authors demonstrated that Coll7al is a strong genetic modifier of the junctional EB that develops in Lamc2-deficient mice. This modifier is defined by variations in 1-3 neighboring amino acids in the noncollagenous 4 domain of the collagen XVII protein ${ }^{43}$. These allelic variants alter the strength of dermal-epidermal adhesion in the context of the Lamc2 mutation and, consequentially, broadly impact the clinical severity of junctional $\mathrm{EB}^{43}$.

Odorisio et al. used an exceptional genetic model to uncover molecular modifiers in dystrophic $\mathrm{EB}^{44}$. They studied a monozygotic twin pair with recessive dystrophic EB presenting different phenotypic manifestations while expressing similar amounts of collagen VII ${ }^{44}$. Gene expression analysis in the twins' fibroblasts showed differential expression of genes associated with transforming growth factor-beta (TGF- $\beta$ ) pathway inhibition. Decorin, a skin matrix component with anti-fibrotic properties, was more abundant in the less affected twin, while both TGF- $\beta$ canonical and non-canonical pathways were more activated in the fibroblasts of the more affected twin. These data showed that the amount of type VII collagen is not the only determinant of clinical severity and indicated an involvement of TGF- $\beta$ pathways in modulating disease variability ${ }^{44}$.

\section{Looking back and forward}

- In spite of the advanced knowledge on the molecular basis of skin fragility, the molecular pathology is still expanding. New mutational mechanisms, genes, and phenotypes still emerge.

- Comprehensive NGS-based genetic testing improved mutation detection and facilitated the identification of the genetic basis of unclear phenotypes. However, this approach did not reveal any novel genetic modifiers in large cohorts of patients. 
- Understanding the biochemical and cell biological consequences of the mutations remains challenging. Such studies significantly deepen our knowledge and represent the basis for personalized therapeutic approaches. They are very laborious and usually not rewarded by the journal impact factor.

- Detailed characterization of the functions of the proteins which were recently implicated in EB, exophilin 5, and KLHL24 is required. Therapeutic implications may emerge.

- EB is one of the privileged "orphan diseases" because the classification has been regularly revised in past decades according to the scientific progress. The complexity of molecular and clinical constellations has constantly increased, rendering the classification system quite complicated for non-specialists. The dilemma is to lump or to split. The aims should be to provide a pragmatic tool and achieve broad adherence and implementation in clinical practice.

- The rigorous and tenacious research of the molecular bases and pathomechanisms of EB is currently rewarded by impressive progress made in EB therapy. Cell therapies, such as bone marrow transplantation ${ }^{45}$ and local or systemic injections with fibroblasts ${ }^{46}$ or mesenchymal stromal cells ${ }^{47}$, showed benefit in reducing wounds, inflammation, and pain in patients with dystrophic EB. Remarkably, the entire epidermis of a boy with junctional $\mathrm{EB}$ could be regenerated by transgenic stem cells ${ }^{48}$.
Aminoglycosides proved effective in providing read-through of premature termination codons in patients with dystrophic $\mathrm{EB}^{49}$, while clinical trials are ongoing to demonstrate the effect of anti-TGF- $\beta$ therapies. Though not available to all people with $\mathrm{EB}$, these procedures provide hope for the future.

\section{Abbreviations}

BPAG1, bullous pemphigoid antigen 1; EB, epidermolysis bullosa; KLHL24, kelch-like protein 24; Lamc2, laminin $\gamma 2$; NGS, next-generation sequencing; TGF- $\beta$, transforming growth factor-beta; VUS, variant of uncertain significance.

\section{Competing interests}

The author declares that she has no competing interests.

\section{Grant information}

Debra International, CRC (SFB) 1140, and the Fritz Thyssen Foundation are acknowledged for funding.

The funders had no role in decision to publish, or preparation of the manuscript.

\section{Acknowledgments}

The author thanks the EB Center Freiburg and all collaborators who have kindly provided samples and clinical information over the past 15 years.
1. Blume-Peytavi U, Tan J, Tennstedt $\mathrm{D}$, et al: Fragility of epidermis in newborns, children and adolescents. J Eur Acad Dermatol Venereol. 2016; 30(Suppl 4): 3-56. PubMed Abstract | Publisher Full Text

2. Kaya G, Saurat JH: Dermatoporosis: a chronic cutaneous insufficiency/fragility syndrome. Clinicopathological features, mechanisms, prevention and potential treatments. Dermatology. 2007; 215(4): 284-94. PubMed Abstract | Publisher Full Text

3. Has C, Bruckner-Tuderman L: The genetics of skin fragility. Annu Rev Genomics Hum Genet. 2014: 15: 245-68.

PubMed Abstract | Publisher Full Text

4. $\quad F$ Fine JD, Bruckner-Tuderman L, Eady RA, et al.: Inherited epidermolysis bullosa: updated recommendations on diagnosis and classification. J Am Acad Dermatol. 2014; 70(6): 1103-26.

PubMed Abstract | Publisher Full Text | F1000 Recommendation

5. F Fine JD, Eady RA, Bauer EA, et al:: The classification of inherited epidermolysis bullosa (EB): Report of the Third International Consensus Meeting on Diagnosis and Classification of EB. J Am Acad Dermatol. 2008; 58(6): 931-50.

PubMed Abstract | Publisher Full Text | F1000 Recommendation

6. $\quad \mathrm{F}$ Takeichi $\mathrm{T}$, Liu L, Fong $\mathrm{K}$, et al.: Whole-exome sequencing improves mutation detection in a diagnostic epidermolysis bullosa laboratory. Br J Dermatol. 2015; 172(1): 94-100.

PubMed Abstract | Publisher Full Text | F1000 Recommendation

7. $\quad F$ Tenedini E, Artuso L, Bernardis I, et al.: Amplicon-based next-generation sequencing: an effective approach for the molecular diagnosis of epidermolysis bullosa. Br J Dermatol. 2015; 173(3): 731-8. PubMed Abstract | Publisher Full Text | F1000 Recommendation

8. $\quad \mathrm{F}$ Vahidnezhad H, Youssefian L, Saeidian AH, et al:: Multigene Next-Generation Sequencing Panel Identifies Pathogenic Variants in Patients with Unknown Subtype of Epidermolysis Bullosa: Subclassification with Prognostic
Implications. J Invest Dermatol. 2017; 137(12): 2649-52.

PubMed Abstract | Publisher Full Text | F1000 Recommendation

9. Has C, Küsel J, Reimer A, et al:: The Position of Targeted Next-generation Sequencing in Epidermo-lysis Bullosa Diagnosis. Acta Derm Venereol. 2017. PubMed Abstract | Publisher Full Text

10. F Lucky AW, Dagaonkar N, Lammers K, et al:: A comprehensive nextgeneration sequencing assay for the diagnosis of epidermolysis bullosa. Pediatr Dermatol. 2018

PubMed Abstract | Publisher Full Text | F1000 Recommendation

11. Maier K, He Y, Esser PR, et al:: Single Amino Acid Deletion in Kindlin-1 Results in Partial Protein Degradation Which Can Be Rescued by Chaperone Treatment. J Invest Dermatol. 2016; 136(5): 920-9. PubMed Abstract | Publisher Full Text

12. $\mathrm{F}$ Nishimura $\mathrm{M}$, Nishie W, Shirafuji $\mathrm{Y}$, et al:: Extracellular cleavage of collagen $\mathrm{XVII}$ is essential for correct cutaneous basement membrane formation. Hum Mol Genet. 2016; 25(2): 328-39.

PubMed Abstract | Publisher Full Text | F1000 Recommendation

13. $\mathrm{F}$ Richards S, Aziz N, Bale S, et al:: Standards and guidelines for the interpretation of sequence variants: a joint consensus recommendation of the American College of Medical Genetics and Genomics and the Association for Molecular Pathology. Genet Med. 2015; 17(5): 405-24. PubMed Abstract | Publisher Full Text | Free Full Text | F1000 Recommendation

14. Chmel N, Danescu S, Gruler A, et al:: A Deep-Intronic FERMT1 Mutation Causes Kindler Syndrome: An Explanation for Genetically Unsolved Cases. J Invest Dermatol. 2015; 135(11): 2876-9. PubMed Abstract | Publisher Full Text

15. He Y, Balasubramanian M, Humphreys N, et al:: Intronic ITGA3 Mutation Impacts Splicing Regulation and Causes Interstitial Lung Disease, Nephrotic Syndrome, and Epidermolysis Bullosa. J Invest Dermatol. 2016; 136(5): 1056-9. PubMed Abstract | Publisher Full Text 
16. Has C, Chmel N, Levati L, et al.: FERMT1 promoter mutations in patients with Kindler syndrome. Clin Genet. 2015; 88(3): 248-54. PubMed Abstract | Publisher Full Text

17. F Turcan I, Pasmooij AM, van den Akker PC, et al:: Heterozygosity for a Novel Missense Mutation in the ITGB4 Gene Associated With Autosomal Dominant Epidermolysis Bullosa. JAMA Dermatol. 2016; 152(5): 558-62. PublMed Abstract | Publisher Full Text | F1000 Recommendation

18. Mayer B, Silló $\mathrm{P}$, Mazán M, et al.: A unique LAMB3 splice-site mutation with founder effect from the Balkans causes lethal epidermolysis bullosa in several European countries. Br J Dermatol. 2016; 175(4): 721-7. PubMed Abstract | Publisher Full Text

19. Walko G, Castañón MJ, Wiche G: Molecular architecture and function of the hemidesmosome. Cell Tissue Res. 2015; 360(3): 529-44. PubMed Abstract | Publisher Full Text | Free Full Text

20. Wiche G, Winter L: Plectin isoforms as organizers of intermediate filament cytoarchitecture. Bioarchitecture. 2011; 1(1): 14-20. PubMed Abstract | Publisher Full Text | Free Full Text

21. Winter $L$, Wiche $G$ : The many faces of plectin and plectinopathies: pathology and mechanisms. Acta Neuropathol. 2013; 125(1): 77-93. PubMed Abstract | Publisher Full Text

22. F Castañón MJ, Walko G, Winter L, et al:: Plectin-intermediate filament partnership in skin, skeletal muscle, and peripheral nerve. Histochem Cell Biol. 2013; 140(1): 33-53.

PubMed Abstract | Publisher Full Text | Free Full Text | F1000 Recommendation

23. Wiche G, Osmanagic-Myers $\mathrm{S}$, Castañón $\mathrm{MJ}$ : Networking and anchoring through plectin: a key to IF functionality and mechanotransduction. Curr Opin Cell Biol. 2015; 32: 21-9.

PubMed Abstract | Publisher Full Text

24. Olaisen B, Gedde-Dahl T Jr: GPT--epidermolysis bullosa simplex (EBS Ogna) linkage in man. Hum Hered. 1973; 23(3): 189-96. PubMed Abstract | Publisher Full Text

25. Koss-Harnes D, Høyheim B, Anton-Lamprecht I, et al:: A site-specific plectin mutation causes dominant epidermolysis bullosa simplex Ogna: two identical de novo mutations. J Invest Dermatol. 2002; 118(1): 87-93. PubMed Abstract | Publisher Full Text

26. Kiritsi D, Pigors M, Tantcheva-Poor I, et al:: Epidermolysis bullosa simplex ogna revisited. J Invest Dermatol. 2013; 133(1): 270-3.

PubMed Abstract | Publisher Full Text

27. $\mathrm{F}$ Bolling MC, Jongbloed JDH, Boven LG, et al:: Plectin mutations underlie epidermolysis bullosa simplex in $\mathbf{8} \%$ of patients. $J$ Invest Dermatol. 2014; 134(1): 273-6.

PubMed Abstract | Publisher Full Text | F1000 Recommendation

28. Walko G, Vukasinovic N, Gross K, et al:: Targeted proteolysis of plectin isoform $1 \mathrm{a}$ accounts for hemidesmosome dysfunction in mice mimicking the dominant skin blistering disease EBS-Ogna. PLoS Genet. 2011; 7(12): e1002396. PubMed Abstract | Publisher Full Text | Free Full Text

29. F Gostyńska KB, Nijenhuis M, Lemmink H, et al:: Mutation in exon 1a of PLEC leading to disruption of plectin isoform 1a, causes autosomal-recessive skinonly epidermolysis bullosa simplex. Hum Mol Genet. 2015; 24(11): 3155-62. PubMed Abstract | Publisher Full Text | F1000 Recommendation

30. Künzli K, Favre B, Chofflon M, et al.: One gene but different proteins and diseases: the complexity of dystonin and bullous pemphigoid antigen 1. Exp Dermatol. 2016; 25(1): 10-6. PubMed Abstract | Publisher Full Text

31. F Takeichi T, Nanda A, Liu L, et al.: Founder mutation in dystonin-e underlying autosomal recessive epidermolysis bullosa simplex in Kuwait. $\mathrm{Br} J$ Dermatol. 2015; 172(2): 527-31.

PubMed Abstract | Publisher Full Text | F1000 Recommendation

32. F Groves RW, Liu L, Dopping-Hepenstal PJ, et al: : A homozygous nonsense mutation within the dystonin gene coding for the coiled-coil domain of the epithelial isoform of BPAG1 underlies a new subtype of autosomal recessive
epidermolysis bullosa simplex. J Invest Dermatol. 2010; 130(6): 1551-7. PubMed Abstract | Publisher Full Text | F1000 Recommendation

33. He $\mathrm{Y}$, Leppert J, Steinke $\mathrm{H}$, et al.: Homozygous Nonsense Mutation and Additional Deletion of an Amino Acid in BPAG1e Causing Mild Localized
Epidermolysis Bullosa Simplex. Acta Derm Venereol. 2017; 97(5): 657-9. PubMed Abstract | Publisher Full Text

34. F Turcan I, Pasmooij AMG, Gostyński A, et al.: Epidermolysis Bullosa Simplex Caused by Distal Truncation of BPAG1-e: An Intermediate Generalized Phenotype with Prurigo Papules. J Invest Dermatol. 2017; 137(10): 2227-30. PubMed Abstract | Publisher Full Text | F1000 Recommendation

35. F Cappuccio G, Pinelli M, Torella A, et al:: Expanding the phenotype of DSTrelated disorder: $\mathrm{A}$ case report suggesting a genotype/phenotype correlation. Am J Med Genet A. 2017; 173(10): 2743-6.

PubMed Abstract | Publisher Full Text | F1000 Recommendation

36. $\quad F$ Lin Z, Li S, Feng C, et al:: Stabilizing mutations of $K L H L 24$ ubiquitin ligase cause loss of keratin 14 and human skin fragility. Nat Genet. 2016; 48(12): $1508-16$

PubMed Abstract | Publisher Full Text | F1000 Recommendation

37. He $\mathrm{Y}$, Maier K, Leppert J, et al.: Monoallelic Mutations in the Translation Initiation Codon of KLHL24 Cause Skin Fragility. Am J Hum Genet. 2016; 99(6): 1395-404.

PubMed Abstract | Publisher Full Text | Free Full Text

38. Has C: The "Kelch" Surprise: KLHL24, a New Player in the Pathogenesis of Skin Fragility. J Invest Dermatol. 2017; 137(6): 1211-2.

PubMed Abstract | Publisher Full Text

39. Dhanoa BS, Cogliati T, Satish AG, et al.: Update on the Kelch-like (KLHL) gene family. Hum Genomics. 2013; 7: 13

PubMed Abstract | Publisher Full Text | Free Full Text

40. Lu A, Pfeffer SR: A CULLINary ride across the secretory pathway: more than just secretion. Trends Cell Biol. 2014; 24(7): 389-99. PubMed Abstract | Publisher Full Text | Free Full Text

41. Laezza F, Wilding TJ, Sequeira S, et al: The BTB/kelch protein, KRIP6, modulates the interaction of PICK1 with GluR6 kainate receptors. Neuropharmacology. 2008; 55(7): 1131-9. PubMed Abstract | Publisher Full Text | Free Full Tex

42. F Lee JYW, Liu L, Hsu CK, et al:: Mutations in KLHL24 Add to the Molecular Heterogeneity of Epidermolysis Bullosa Simplex. J Invest Dermatol. 2017; 137(6): 1378-80.

PubMed Abstract | Publisher Full Text | F1000 Recommendation

43. F Sproule TJ, Bubier JA, Grandi FC, et al.: Molecular identification of collagen 17 a1 as a major genetic modifier of laminin gamma 2 mutation-induced junctional epidermolysis bullosa in mice. PLoS Genet. 2014; 10(2): e1004068. PubMed Abstract | Publisher Full Text | Free Full Text | F1000 Recommendation

44. F Odorisio T, Di Salvio M, Orecchia A, et al:: Monozygotic twins discordant fo recessive dystrophic epidermolysis bullosa phenotype highlight the role of TGF- $\beta$ signalling in modifying disease severity. Hum Mol Genet. 2014; 23(15): 3907-22.

PubMed Abstract | Publisher Full Text | F1000 Recommendation

45. $\quad \mathrm{F}$ Wagner JE, Ishida-Yamamoto A, McGrath JA, et al.: Bone marrow transplantation for recessive dystrophic epidermolysis bullosa. $N$ Engl $\mathrm{J} \mathrm{Med}$. 2010; 363(7): 629-39.

PubMed Abstract | Publisher Full Text | Free Full Text | F1000 Recommendation

46. F Petrof G, Martinez-Queipo M, Mellerio JE, et al:: Fibroblast cell therapy enhances initial healing in recessive dystrophic epidermolysis bullosa wounds: results of a randomized, vehicle-controlled trial. Br J Dermatol. 2013; 169(5): 1025-33.

PubMed Abstract | Publisher Full Text | F1000 Recommendation

47. F Petrof G, Lwin SM, Martinez-Queipo M, et al:: Potential of Systemic Allogeneic Mesenchymal Stromal Cell Therapy for Children with Recessive Dystrophic Epidermolysis Bullosa. J Invest Dermatol. 2015; 135(9): 2319-21. PubMed Abstract | Publisher Full Text | Free Full Text | F1000 Recommendation

48. F Hirsch T, Rothoeft T, Teig N, et al.: Regeneration of the entire human epidermis using transgenic stem cells. Nature. 2017; 551(7680): 327-32. PubMed Abstract | Publisher Full Text | F1000 Recommendation

49. F Woodley DT, Cogan J, Hou Y, et al.: Gentamicin induces functional type VII collagen in recessive dystrophic epidermolysis bullosa patients. $J$ Clin Invest. 2017; 127(8): 3028-38.

PubMed Abstract | Publisher Full Text | Free Full Text | F1000 Recommendation 


\section{Open Peer Review}

\section{Current Peer Review Status:}

\section{Editorial Note on the Review Process}

Faculty Reviews are review articles written by the prestigious Members of Faculty Opinions. The articles are commissioned and peer reviewed before publication to ensure that the final, published version is comprehensive and accessible. The reviewers who approved the final version are listed with their names and affiliations.

\section{The reviewers who approved this article are:}

\section{Version 1}

\section{Jakub Tolar}

Department of Pediatrics, University of Minnesota, Minneapolis, MN, USA

Competing Interests: No competing interests were disclosed.

\section{Gerhard Wiche}

Department of Biochemistry \& Cell Biology, Perutz Laboratories, University of Vienna, Vienna, Austria

Competing Interests: No competing interests were disclosed.

The benefits of publishing with F1000Research:

- Your article is published within days, with no editorial bias

- You can publish traditional articles, null/negative results, case reports, data notes and more

- The peer review process is transparent and collaborative

- Your article is indexed in PubMed after passing peer review

- Dedicated customer support at every stage

For pre-submission enquiries, contact research@f1000.com 